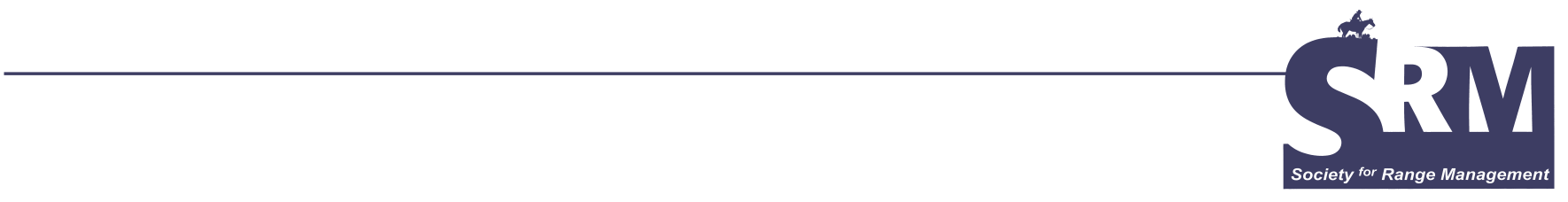

\title{
USDA-ARS Global Change Research on Rangelands and Pasturelands
}

\author{
By Justin D. Derner, Gerald E. Schuman, Michael Jawson, \\ Steven R. Shafer, Jack A. Morgan, H. Wayne Polley, G. Brett \\ Runion, Stephen A. Prior, H. Allen Torbert, Hugo H. Rogers, \\ James Bunce, Lewis Ziska, Jeffrey W. White, Alan J. \\ Franzluebbers, Jean D. Reeder, Rodney T. Venterea, and \\ Lowry A. Harper
}

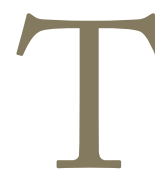
he topic of global change is found almost daily in newspaper and magazine articles and on television. Global change refers to large-scale changes in the Earth's biological, geological, hydrological, and atmospheric systems, whether of human or natural origin. The primary concern of global change has centered on the rapid increase in atmospheric concentrations of primary greenhouse gases (carbon dioxide $\left[\mathrm{CO}_{2}\right]$, methane $\left[\mathrm{CH}_{4}\right]$, and nitrous oxide $\left[\mathrm{N}_{2} \mathrm{O}\right]$ ) since the Industrial Revolution in the latter part of the 19 th century. ${ }^{1}$ Increased concentrations of all 3 of these gases trap more of the sun's energy close to Earth's surface and lead to global warming, hence the reason that these gases are often referred to as "greenhouse gases." The concentration of $\mathrm{CO}_{2}$ has increased by about $35 \%$ compared to preindustrial times and is predicted to reach twice the preindustrial concentration within the 21 st century. ${ }^{2}$ Plants convert $\mathrm{CO}_{2}$ in the air into plant tissue, so $\mathrm{CO}_{2}$ enrichment generally stimulates plant growth and improves the efficiency with which plants use water. ${ }^{3}$ These changes, in turn, influence plant nutrition and the cycling of carbon and other mineral elements through the soil/plant system ${ }^{4}$ and may have long-lasting ecological consequences for rangelands and pasturelands. For example, increased plant production with $\mathrm{CO}_{2}$ enrichment ${ }^{5,6}$ requires additional soil nitrogen, which is limiting in most rangeland and pasture- land ecosystems, and this will modify nutrient cycling because less nitrogen is available for soil microorganisms to decompose plant materials.

The increase in methane and nitrous oxide concentrations in the atmosphere that have occurred are also a cause for concern as their warming potential as greenhouse gases surpasses that of $\mathrm{CO}_{2}{ }^{7}$ Global warming is predicted to have numerous impacts on our climate, including altered precipitation patterns and a potential rise in sea levels. As such, global warming may have profound impacts on human activities and enterprises and is thus a concern to many. Rangelands and pasturelands provide much of the world's food and fiber, and because they occupy an extensive land area, changes in how these lands function could increase or reduce the atmospheric load of greenhouse gases. For example, land management strategies that increase the storage of carbon in plant biomass and/or soil organic matter on rangelands and pasturelands, in a process termed "carbon sequestration," offer opportunities to mitigate the rise in atmospheric $\mathrm{CO}_{2}$ concentrations. ${ }^{8}$

To evaluate potential impacts that increasing concentrations of greenhouse gases may have, the United States Department of Agriculture-Agricultural Research Service (USDA-ARS), in its Natural Resources and Sustainable Agricultural Systems program, established a Global Change 


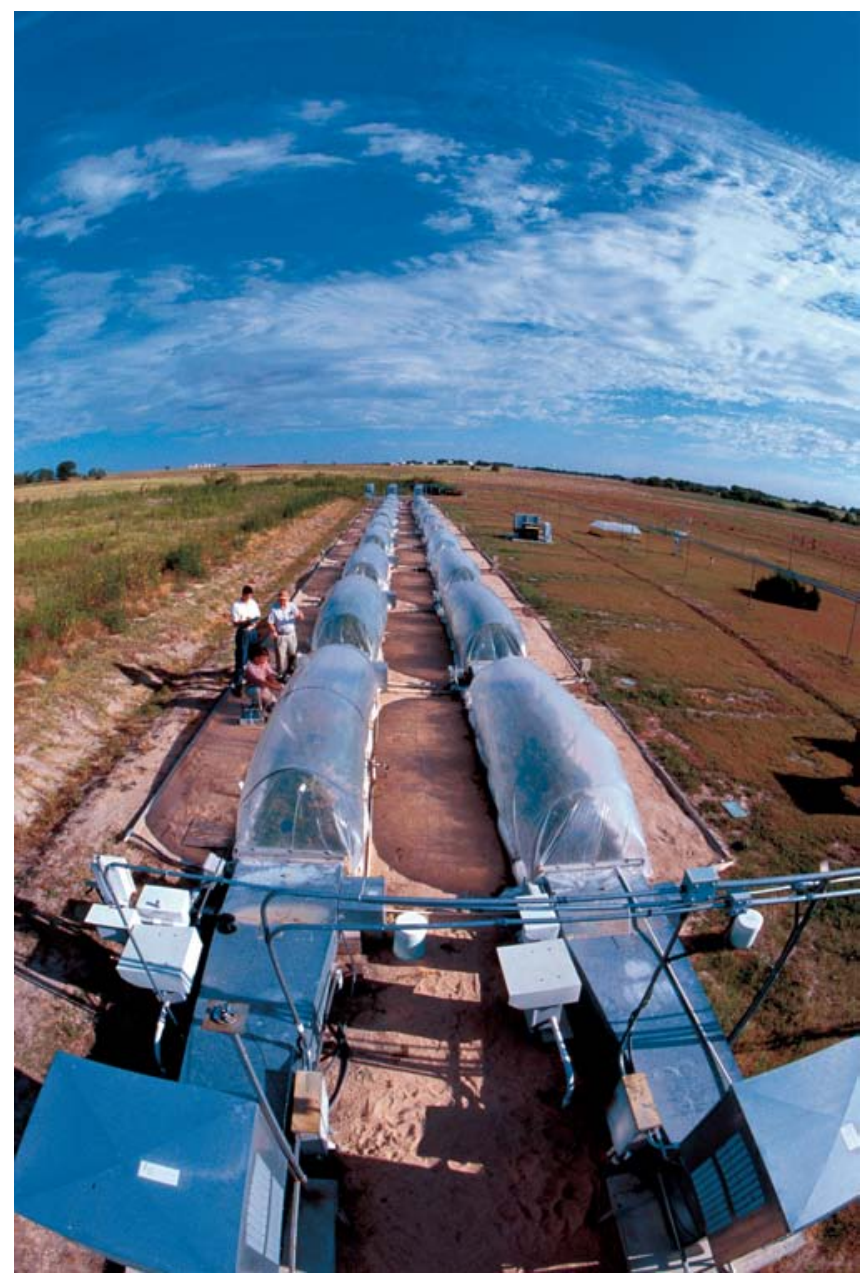

Figure 1. Field experiment at Temple, Texas, used to study the influence of increasing atmospheric $\mathrm{CO}_{2}$ on mesic rangelands. Photo courtesy of Scott Bauer.

National Program. An Action Plan, written in 2000 following customer and stakeholder workshops, identified 4 main components: 1) carbon cycle and carbon storage, 2) trace gases, 3) agricultural ecosystem impacts, and 4) changes in weather and the water cycle at farm, ranch, and regional scales (http://www.ars.usda.gov/research/programs/programs.htm?NP_CODE=204). The USDA-ARS has also formed a "Greenhouse gas Reduction through Agricultural Carbon Enhancement network” (GRACEnet) comprising over 25 research locations representing a broad range of climatic, land use, and soil variables with objectives of 1) determining effects of agricultural management practices on carbon sequestration and storage, trace gas emissions, and environmental quality; 2) providing land managers with practices and strategies that can be used to both mitigate greenhouse gases and improve soil quality; and 3) providing policy and decision makers with information on agricultural practices and strategies that can be used to mitigate and adapt to global change. This network is evaluating 4 proposed agricultural land management intensity scenarios encompassing 1 ) business as usual (most typical land management practice in the region), 2) maximizing carbon sequestration, 3) maximizing carbon sequestration and reducing greenhouse gas emissions (global warming potential), and 4) maximizing net environmental benefits to include air and water quality along with reducing greenhouse gas emissions.

A special symposium titled "Global Change in Rangelands and Pasturelands: A State of the State" was held at the 58th annual meeting of the SRM in Fort Worth, Texas, on February 8, 2005, in which USDA-ARS scientists provided information on 1) what is known regarding the influence of increasing atmospheric $\mathrm{CO}_{2}$ on rangeland and pastureland soils and plant communities, and 2) how land management practices on rangelands and pasturelands might mitigate global change through the GRACEnet proposed scenarios. The following is a summary of those presentations; the scientist is identified so the reader may contact him or her directly for further information on a specific topic.

\section{Session 1: Influence of Increasing Atmospheric $\mathrm{CO}_{2}$ on Rangelands and Pasturelands \\ Semiarid Rangelands: Jack Morgan (Jack.Morgan@ars.usda.gov)}

In semiarid rangelands, it is the indirect effect that increased atmospheric levels of $\mathrm{CO}_{2}$ has on plant-water relations that may be most important in driving ecosystem responses to $\mathrm{CO}_{2}$. These water relations can result in substantial increases in net primary production, and responses suggest that semiarid rangelands may be among the world's more responsive ecosystems to rising $\mathrm{CO}_{2}{ }^{3,9}$ However, $\mathrm{CO}_{2}$-enhanced productivity is accompanied by lower forage nitrogen concentration and reduced digestibility. ${ }^{6}$ Thus, even though plant production is stimulated by elevated $\mathrm{CO}_{2}$, the biomass produced is of poorer quality and is less desirable for livestock and wildlife. In addition, different responses among plant species to elevated $\mathrm{CO}_{2}$ cause significant shifts in plant community species composition with important ecological and management implications/consequences.

Although much has been learned from small-plot $\mathrm{CO}_{2}$ enrichment experiments, there are still major gaps in our knowledge, including the assessment of multiple factors involved in climate change under more natural conditions. A major challenge in $\mathrm{CO}_{2}$ enrichment research is in determining how to interpret short-term experiments that are conducted as small, elevated $\mathrm{CO}_{2}$ islands in otherwise presentday environments. While the incremental changes used in global change studies, such as doubling the $\mathrm{CO}_{2}$ concentration above present ambient levels, may be useful for studying the effects of $\mathrm{CO}_{2}$ on ecosystem processes like soil/plant/water relations, photosynthesis and net primary production, they may not provide accurate information on more slowly evolving ecosystem traits like soil nutrient cycling, individual plant species response, or plant species shifts. Further, such instantaneous changes in $\mathrm{CO}_{2}$ concen- 
tration do not accurately simulate the continuous and incremental increases in $\mathrm{CO}_{2}$ the Earth is experiencing.

\section{Mesic Rangelands: H. Wayne Polley \\ (wpolley@spa.ars.usda.gov)}

Increasing $\mathrm{CO}_{2}$ from preindustrial to an elevated concentration stimulated grassland production in central Texas by increasing the rate of $\mathrm{CO}_{2}$ uptake by plants and by reducing the rate of water loss from leaves. ${ }^{5} \mathrm{CO}_{2}$ enrichment accelerated a successional change in vegetation composition from dominance by warm-season grasses to codominance between grasses and broad-leaved herbaceous plants (forbs), such that the positive response of grassland biomass to increasing $\mathrm{CO}_{2}$ was impacted by different species or groups of species during different years. ${ }^{5}$

The amount of additional carbon that can be fixed by plants and retained in soils is ultimately constrained by the availability of nitrogen. In order for rangelands to remain responsive to $\mathrm{CO}_{2}$ for long time periods (decades to centuries), soil nitrogen supplies will likely need to be increased. For extensively managed ecosystems like rangelands, nitrogen availability could be increased by reducing nitrogen losses from leaching and gaseous emissions or by increasing the amount of nitrogen fixed by legumes. Whether these processes will be promoted by the continuous and incremental increases in $\mathrm{CO}_{2}$ that are occurring in nature remains to be resolved.

\section{Southeastern Pasture: G. Brett Runion, Stephen A. Prior, H. Allen Torbert, and Hugo H. Rogers (gbrunion@msa-stoneville.ars.usda.gov)}

Pastures occupy 80 million acres in the southeastern United States, which is about $75 \%$ of the total pasture acreage in the eastern United States. ${ }^{10}$ Rising $\mathrm{CO}_{2}$ could impact pasture production and subsequent sequestration of soil carbon. Although the response of rangelands to rising $\mathrm{CO}_{2}$ has been an important area of investigation for several years, managed pastures have received little attention with respect to global change.

The response of a southeastern pasture system (bahiagrass, Paspalum notatum) to current (365 ppm) and elevated (725 ppm) levels of $\mathrm{CO}_{2}$ is being examined in a recently initiated experiment. After an establishment period, a nitrogen management factor (low nitrogen fertility $=$ no nitrogen added vs high nitrogen fertility $=180$ pounds of nitrogen per acre per year) will be added to the research. This study will examine the effects of $\mathrm{CO}_{2}$ and soil nitrogen on growth and function of above- and belowground plant parts as well as changes in soil organic carbon and nitrogen, including assessing the potential of this pasture system to sequester $\mathrm{CO}_{2}$ as soil carbon and the influence on trace gas emissions $\left(\mathrm{CO}_{2}, \mathrm{CH}_{4}\right.$, and $\left.\mathrm{N}_{2} \mathrm{O}\right)$.

\section{Weeds: James Bunce and Lewis Ziska (buncej@ba.ars.usda.gov)}

Despite their large economic impact, weeds have received little attention in field studies investigating the effects of $\mathrm{CO}_{2}$ enrichment in croplands, pastures, and rangelands.

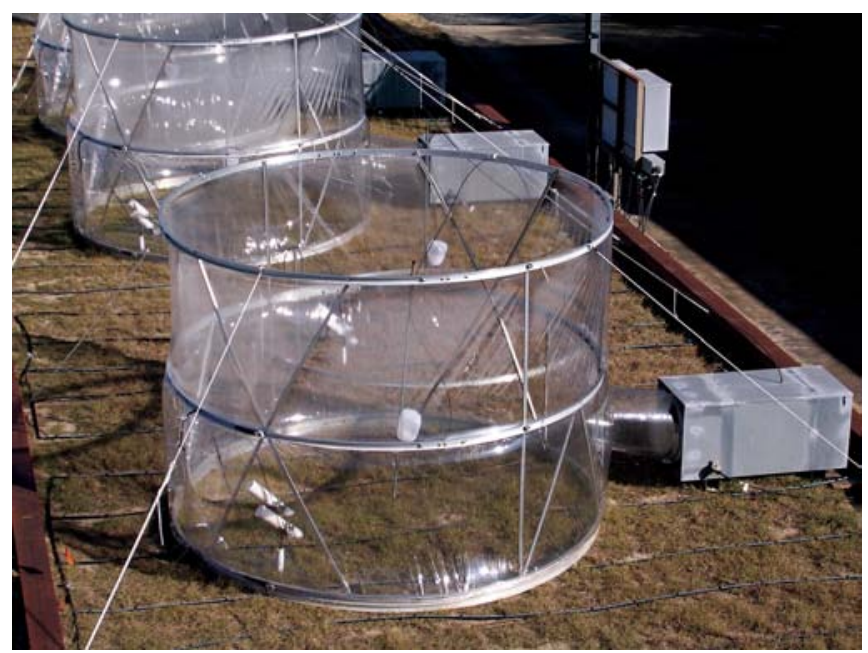

Figure 2. Field experiment at Auburn, Alabama, used to study the influence of increasing atmospheric $\mathrm{CO}_{2}$ on southeastern pastures. Photo courtesy of Stephen Prior.

However, in recent years there have been a few comparisons of yield losses resulting from weeds in annual cropping systems at current and projected $\mathrm{CO}_{2}$ concentrations. Elevated $\mathrm{CO}_{2}$ often favors the most rapidly growing species or those active earliest in the growing season, which are frequently weeds. ${ }^{11}$ The responsiveness of plants grown in isolation to elevated $\mathrm{CO}_{2}$, however, is often a poor predictor of their responsiveness in competitive situations.

One of the major unknowns in predicting the impact of rising $\mathrm{CO}_{2}$ on rangelands is how rapidly genetic adaptation to rising $\mathrm{CO}_{2}$ occurs in weeds and in the species with which they compete. If evolution occurs more rapidly in weeds, then the changes in productivity or in community composition observed in experiments where $\mathrm{CO}_{2}$ is suddenly increased may differ from those that will occur with a more gradual increase in $\mathrm{CO}_{2}$.

\section{Modeling Efforts: Jeff White \\ (JWhite@uswcl.ars.ag.gov)}

Field experiments provide the foundation for understanding how factors such as weather, soil conditions, and management interact to affect productivity in rangelands and pasturelands. However, the complexities of the underlying processes are often so great that researchers use computerbased models to complement field studies. Models of single species generally confirm the expectation that increasing $\mathrm{CO}_{2}$ leads to increased photosynthesis and growth while reducing requirements for water and nitrogen. ${ }^{12}$ Under conditions of low soil fertility, plant species (typically legumes) that convert atmospheric nitrogen to forms usable by plants may benefit more from increasing $\mathrm{CO}_{2}$.

Uncertainties increase, however, as more quantitative predictions are sought. A difficult problem is anticipating likely genetic adaptations to increased $\mathrm{CO}_{2}$ and how this would influence predicted impacts. For example, plants might 
evolve that have greater photosynthesis capacity than current genotypes, but these plants also may consume much more water and nitrogen. Research is under way to model how genetic variability might affect plant response to $\mathrm{CO}_{2}$, but our understanding of the details of how elevated $\mathrm{CO}_{2}$ affects photosynthesis and plant water is still incomplete.

\section{Session 2: Land Management Practices on Rangelands and Pasturelands to Mitigate Global Change Grazing Management Effects on Carbon Storage in Pastures: Alan J. Franzluebbers (afranz@uga.edu)}

Pastures (improved, native, and naturalized) are grown on approximately 125 million acres of private land in the United States. Soil organic carbon has been shown to increase on these lands by approximately 0.5 tons of carbon per acre per year with grass establishment compared to cultivated cropland, ${ }^{13}$ and cool-season plants such as tall fescue accumulate more soil organic carbon than warm-season plants such as bermudagrass. ${ }^{14}$ This is because cool-season plants have a wider window of growth opportunities to utilize soil water and produce plant tissue carbon. The application of fertilizer can be used to enhance forage production to restore soil organic carbon following decades of crop cultivation; both inorganic and organic (animal manure) fertilizers have been shown to be equally effective in increasing soil organic carbon in pastures. ${ }^{15}$ Soil organic carbon in bermudagrass pastures can also be increased by grazing at low to moderate rates compared to haying or no grazing. ${ }^{15}$

A significant effort has been invested in forage management and grazing studies in the eastern United States, but these efforts have focused primarily on plant and animal responses with little emphasis devoted to soil responses. Many management issues concerning carbon sequestration in forage-based management systems remain unresolved, including the type of forage species that provide the greatest carbon accumulation, whether carbon sequestration and economic return to producers have similar guidelines, the effect of soil type on management-induced soil responses, and a description of the biophysical limits under which grazing systems may result in negative or positive effects on carbon cycling and ecological function. More information is needed to enable development of specific management practices for effectively integrating cattle and crop production systems within the context of mitigating greenhouse gases.

\section{Grazing Management Effects on Carbon Storage in Rangelands: Gerald E. Schuman and Justin D. Derner (Jerry.Schuman@ars.usda.gov)}

Lands grazed by wild and domesticated animals comprise 830 million acres in the United States, with $48 \%$ of those acres classified as rangelands. Globally, rangelands account for more than one-third of the world's terrestrial carbon reserves. ${ }^{16}$ Because of this large land area, rangelands can sequester a significant amount of additional carbon from the atmosphere. Management practices such as grazing, nitrogen inputs (fertilizer or legume introduction), revegetation of degraded lands, fire, and the use of improved plant species can all increase soil organic carbon storage in rangelands. Properly managed rangelands of the United States are estimated to have the capacity to sequester 19 million tons of carbon per year. ${ }^{17}$ Improving management on 279 million acres of poorly managed US rangelands would sequester 11 million additional tons of carbon annually ${ }^{17}$ An additional 43 million tons of carbon per year could be preserved (avoided losses of carbon) in well-managed rangelands if good management were continued, no rangelands were broken out for cultivation, and reestablished perennial grasslands (Conservation Reserve Program) were maintained as grasslands and not recultivated. ${ }^{17}$

\section{Grazing Management Effects on Inorganic Carbon Storage in Rangelands: Jean D. Reeder \\ (Jean.Reeder@ars.usda.gov)}

Research on carbon storage in rangelands has focused primarily on the influence of land management practices on soil organic carbon. Yet in many arid and semiarid rangelands, inorganic carbon in the form of calcium and magnesium carbonates is a major component of soil carbon. Soil inorganic carbon has been thought to be little influenced by land management practices since the turnover time is much slower than for organic carbon. Research in a short-grass steppe ecosystem demonstrated that both soil organic and inorganic carbon were higher under heavy grazing than no grazing, and inorganic carbon represented proportionally more (69\%) of the increased soil carbon pool than soil organic carbon (31\%). ${ }^{18}$ The data indicate that most of the higher level of inorganic carbon with heavy grazing was the result of redistribution of existing carbonates associated with a shift in plant community composition and soil water dynamics; it

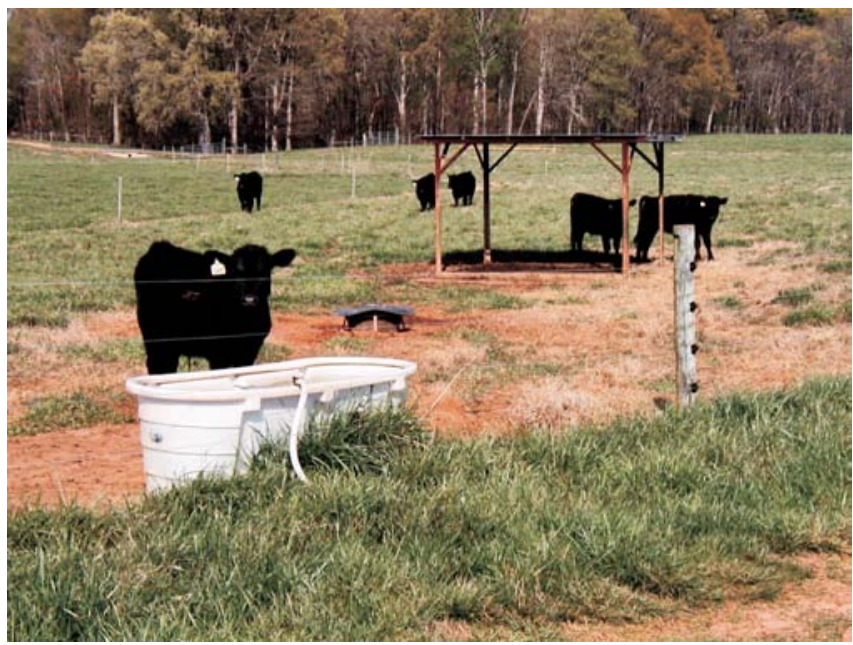

Figure 3. Livestock grazing on pasture in Georgia increases soil carbon storage. Photo courtesy of Alan Franzluebbers. 
remains unclear if soil inorganic carbon is being gained or lost and at what rate. Additional questions remain regarding the influence that redistribution of soil inorganic carbon in the profile may have on other soil properties, such as soil $\mathrm{pH}$ or phosphorus availability.

\section{Impacts of Agricultural Management Practices on Non- $\mathrm{CO}_{2}$ Greenhouse Gas Emissions: Rod Venterea (venterea@umn.edu)}

Biochemical processes occurring within the soil are very important in regulating atmospheric levels of the non- $\mathrm{CO}_{2}$ greenhouse gases $\mathrm{CH}_{4}$ and $\mathrm{N}_{2} \mathrm{O}$. Rangeland and pasture management can significantly alter these biochemical processes. Nitrogen fertilizer use is responsible for more than $70 \%$ of the increase in $\mathrm{N}_{2} \mathrm{O}$ emissions because soil microbes convert a portion of the fertilizer nitrogen to $\mathrm{N}_{2} \mathrm{O}$ gas. ${ }^{19}$ Other microbes that remove $\mathrm{CH}_{4}$ from the atmosphere are negatively affected by fertilizer use and also by increased tillage and cultivation..$^{20,21}$ Irrigation of semiarid lands can cause both an increase in soil $\mathrm{N}_{2} \mathrm{O}$ emissions and a decrease in soil $\mathrm{CH}_{4}$ uptake. ${ }^{22}$

The large land area represented by rangelands means that even small alterations in these processes per unit area have the potential to generate large impacts. Because of the limited number of studies examining the effects of range management on $\mathrm{CH}_{4}$ and $\mathrm{N}_{2} \mathrm{O}$ fluxes, we cannot accurately extrapolate these findings to global or even national scales. Other important areas for which there is little information are 1) how efforts to manage rangeland for increased carbon sequestration may affect non- $\mathrm{CO}_{2}$ greenhouse gases and 2) how changes in environmental conditions such as increased soil temperature and shifts in geographic distribution of plant species may affect soil processes regulating atmospheric $\mathrm{CH}_{4}$ and $\mathrm{N}_{2} \mathrm{O}$ levels.

\section{Methane Emissions from Grazing and Feedlot Cattle: Measurement, Treatments, and Results: Lowry A. Harper (Iharper@uga.edu)}

About $63 \%$ of all agricultural methane production in the United States is contributed by livestock digestion-related emissions; manure decomposition contributes $32 \%$, and rice production produces another $5 \%$. Three micrometeorological techniques have been developed to measure methane production by cattle in pasture and feedlot conditions with minimal disturbance. These techniques can monitor methane continuously for extended periods, allow for short-term observations (1-15-minute samples) to assess activity and diurnal effects, permit small to large numbers of livestock to be sampled, and are virtually nonintrusive to the livestock being evaluated. An integrated horizontal flux technique was developed to measure emissions from a small number of livestock $(<6){ }^{23} \mathrm{~A}$ modification of this technique using open-path laser spectrometry was developed to measure emissions from an intermediate number (10-25) of livestock. ${ }^{24}$ These techniques may be verified using tracer-released methane. To assess methane emis- sions from a large number of livestock (50-100,000 animals), a dispersion analysis technique was developed (backward Lagrangian stochastic analysis) for remotely determining trace gases including methane and ammonia. ${ }^{25}$

Grazing animals emit more methane on an animal and per-animal-weight basis than feedlot animals. Livestock treated with methane-production inhibitors can reduce digestion-related emissions. Measurement of digestionrelated emissions using noninterference techniques has provided more realistic emissions associated with livestock activity and grazing/feeding patterns.

\section{Summary}

Scientists with the USDA-ARS, together with university scientists and other stakeholders, are cooperating to determine effects of global change on rangelands and pasturelands and management practices to mitigate these effects. These coordinated research efforts across several locations in the United States are evaluating long-term impacts of global change on a variety of ecosystem processes, including plant community dynamics and nitrogen and carbon cycling, under different climatic conditions and across environmental gradients.

Several significant advances have been made regarding plant and soil responses to increasing atmospheric $\mathrm{CO}_{2}$ and land management practices to mitigate global change. First, elevated $\mathrm{CO}_{2}$ levels can significantly impact rangeland plant community dynamics, increase water use efficiency, and reduce nitrogen content of the plant material. Whether these plant community shifts and plant responses to single, large increases in $\mathrm{CO}_{2}$ reflect what happens as continuous and incremental increases in $\mathrm{CO}_{2}$ occur over decades remains unknown because plants and soil microorganisms possess the ability to genetically adapt to rising $\mathrm{CO}_{2}$; therefore, this area of research merits further attention. Second, land management practices, such as grazing, fertilization, fire, and introduction of legumes and improved grass species, can increase soil organic carbon storage in rangelands and pasturelands. However, these carbon-directed management practices will need to be evaluated in terms of their impact on other ecosystem goods and services rangelands offer to fully evaluate their potential and sustainability. Third, the development of noninterference methods offers promise to monitor methane emission from isolated animals to large feedlots. Our knowledge of how trace gas emissions $\left(\mathrm{N}_{2} \mathrm{O}\right.$ and $\left.\mathrm{CH}_{4}\right)$ are affected by increasing atmospheric $\mathrm{CO}_{2}$ and land management practices is still growing, and available data are still too limited to extrapolate to large landscape situations with certainty, so additional research is needed in this area.

Our challenge now is to better integrate available knowledge and to scale our understanding, obtained primarily in small patch-scale experiments, to landscape and regional levels if we hope to construct realistic greenhouse gas budgets and management strategies for mitigating greenhouse gases. We also need to do a better job of predicting long-term effects of global change on world ecosystems, including rangeland and 
pastureland systems, to better prepare for a future that will likely feature higher atmospheric $\mathrm{CO}_{2}$, altered precipitation patterns, and warmer temperatures. Better knowledge will be key to the development of intelligent and sustainable management practices that will serve society's needs and preserve our natural resource base. In conclusion, the charge for the Global Change National Program of the USDA-ARS is to continue to make significant inroads in understanding how global change affects rangelands and pasturelands and how management and cultural practices on these lands may aid in the mitigation of global change impacts.

Authors are Rangeland Scientist (Derner) and Soil Scientist (Schuman), US Department of Agriculture-Agricultural Research Service (USDA-ARS), Cheyenne, WY 82009-8899; National Program Leader for Global Change, USDA-ARS, Beltsville, MD 20705-5140 (Jarwson); Associate Area Director, Midwest Area and former National Program Leader for Global Change, USDA-ARS, Peoria, IL 61604 (Shafer); Plant Physiologist, USDA-ARS, Fort Collins, CO 80526-2083 (Morgan); Ecologist, USDA-ARS, Temple, TX 76502-6712 (Polley); Plant Pathologist (Runion), Plant Physiologist (Prior), Soil Scientist (Torbert), and Plant Physiologist (Rogers), USDA-ARS, Auburn, AL 36832; Plant Physiologists, USDAARS, Beltsville, MD 20705-2350 (Bunce and Ziska); Plant Physiologist, USDA-ARS, Phoenix, AZ 85040 (White); Ecologist, USDA-ARS, Watkinsville, GA 30677-2373 (Franzluebbers); Soil Scientist, USDA-ARS, Fort Collins, CO 80526-2083 (Reeder); Soil Scientist, USDA-ARS, St. Paul, MN 55108 (Venterea); and Soil Scientist, USDA-ARS, Watkinsville, GA 30677-2373 (Harper).

\section{References}

1. IPCC, Working Group 1 Third Assessment Report. 2001. Climate change 2001: The scientific basis. Cambridge, UK: Cambridge University Press. $881 \mathrm{p}$.

2. Alcamo, J., G. J. J. Kreileman, J. C. Bollen, G. J. van den Born, R. Gerlagh, M. S. Krol, A. M. C. Toet, and H. J. M. DE VRIES. 1996. Baseline scenarios of global environmental change. Global Environmental Change 6:261-303.

3. Morgan, J. A., D. E. Pataki, C. Körner, H. Clark, S. J. Del Grosso, J. M. Grünzweig, A. K. Knapp, A. R. Mosier, P. C. D. Newton, P. A. Niklaus, J. B. Nippert, R. S. Nowak, W. J. Parton, H. W. Polley, And M. R. Shaw. 2004. Water relations in grassland and desert ecosystems exposed to elevated atmospheric $\mathrm{CO}_{2}$. Oecologia 140:11-25.

4. Torbert, H. A., S. A. Prior, H. H. Rogers, and C. W. WoOD. 2000. Review of elevated atmospheric $\mathrm{CO}_{2}$ effects on agro-ecosystems: residue decomposition processes and soil $\mathrm{C}$ storage. Plant and Soil 224:59-73.

5. Polley, H. W., H. B. Johnson, And J. D. Derner. 2003. Increasing $\mathrm{CO}_{2}$ from subambient to superambient concentrations alters species composition and increases above-ground biomass in a $\mathrm{C}_{3} / \mathrm{C}_{4}$ grassland. New Phytologist 160:319-327.
6. Morgan, J. A., A. R. Mosier, D. G. Milchunas, D. R. LeCain, J. A. Nelson, and W. J. Parton. 2004. $\mathrm{CO}_{2}$ enhances productivity, alters species composition, and reduces forage digestibility of shortgrass steppe vegetation. Ecological Applications 14:208-219.

7. Mosier, A. R., W. J. Parton, and S. Phongpan. 1998. Long-term large $\mathrm{N}$ and immediate small $\mathrm{N}$ addition effects on trace gas fluxes in the Colorado shortgrass steppe. Biology and Fertility of Soils 28:44-50.

8. Izaurralde, R. C., N. J. RosenberG, AND R. LAL. 2001. Mitigation of climatic change by soil carbon sequestration: issues of science, monitoring, and degraded lands. Advances in Agronomy 70:1-75.

9. Nowak, R. S., D. S. Ellsworth, and S. D. Smith. 2004. Functional responses of plants to elevated atmospheric $\mathrm{CO}_{2}-$ do photosynthetic and productivity data from FACE experiments support early predictions? New Phytologist 162:253-280.

10. Ball, D. M., C. S. Hoveland, and G. D. Lacefield. 2002. Southern forages: Modern concepts for forage crop management. Norcross, GA: The Potash and Phosphate Institute and the Foundation for Agronomic Research. 322 p.

11. Bunce, J. A. 2001. Weeds in a changing climate. British Crop Protection Council Proceedings 77:109-118.

12. Tubiello, F. N., AND F. EwERT. 2002. Simulating the effects of elevated $\mathrm{CO}_{2}$ on crops approaches and applications for climate change. European Journal of Agronomy 18:57-74.

13. Franzluebbers, A. J. 2005. Soil organic carbon sequestration and agricultural greenhouse gas emissions in the southeastern USA. Soil and Tillage Research 83:120-147.

14. Franzluebbers, A. J., J. A. Stuedemann, H. H. Schomberg, And S. R. Wilkinson. 2000. Soil organic C and $\mathrm{N}$ pools under long-term pasture management in the Southern Piedmont USA. Soil Biology and Biochemistry 32:469-478.

15. Franzluebbers, A. J., J. A. Stuedemann, And S. R. WilkinSON. 2001. Bermudagrass management in the Southern Piedmont USA: I. Soil and surface residue carbon and sulfur. Soil Science Society of America Journal 65:834-841.

16. Allen-DiaZ, B. 1996. Rangelands in a changing climate: impacts, adaptations and mitigation. In: R. T. Watson, M. C. Zinyowera, and R. H. Moss [eds.]. Climate change 1995. Impacts, adaptations, and mitigation of climate change: Scientific-technical analyses. International Panel on Climate Change. Cambridge, UK: Cambridge University Press. p 131-158.

17. Schuman, G. E., J. E. Herrick, And H. H. Janzen. 2001. The dynamics of soil carbon in rangeland. In: R. F. Follett, J. M. Kimble, and R. Lal [eds.]. The potential of U.S. grazing lands to sequester carbon and mitigate the greenhouse effect. Boca Raton, FL: Lewis Publishers. p 267-290.

18. Reeder, J. D., G. E. Schuman, J. A. Morgan, And D. R. LECAIN. 2004. Response of organic and inorganic carbon and nitrogen to long-term grazing of the shortgrass steppe. Environmental Management 33:485-495.

19. Kroeze, C., A. Mosier, And L. Bouwman. 1999. Closing the $\mathrm{N}_{2} \mathrm{O}$ budget: a retrospective analysis 1500-1994. Global Biogeochemical Cycles 13:1-8. 
20. Mosier, A., D. Schimel, D. Valentine, K. Bronson, And W. Parton. 1991. Methane and nitrous oxide fluxes in native, fertilized and cultivated grasslands. Nature 350:330-332.

21. HüTsCH, B. W. 2001. Methane oxidation in non-flooded soils as affected by crop production. European Journal of Agronomy 14:237-260.

22. Mosier, A., W. J. Parton, D. W. Valentine, D. S. Ojima, D. S. Schimel, AND J. A. Delgado. 1996. $\mathrm{CH}_{4}$ and $\mathrm{N}_{2} \mathrm{O}$ fluxes in the Colorado shortgrass steppe: 1 . Impact of landscape position and nitrogen addition. Global Biogeochemical Cycles 10:387-399.
23. Harper, L. A., O. T. Denmead, J. R. Freney, and F. M. Byers. 1999. Direct measurements of methane emissions from grazing and feed lot cattle. Journal of Animal Science 77:1392-1401.

24. Desjardins, R. L., O. T. Denmead, L. A. Harper, M. McBain, D. Masse, And S. Kaharabata. 2004. Evaluation of a micrometeorological mass balance method employing open-path laser for measuring methane emissions. Atmospheric Environment 38:6855-6866.

25. Flesch, T. K., J. D. Wilsoon, And L. A. Harper. 2005. Deducing ground-air emissions from observed trace gas concentrations: a field trial with wind disturbance. Journal of Applied Meteorology 44:475-484.

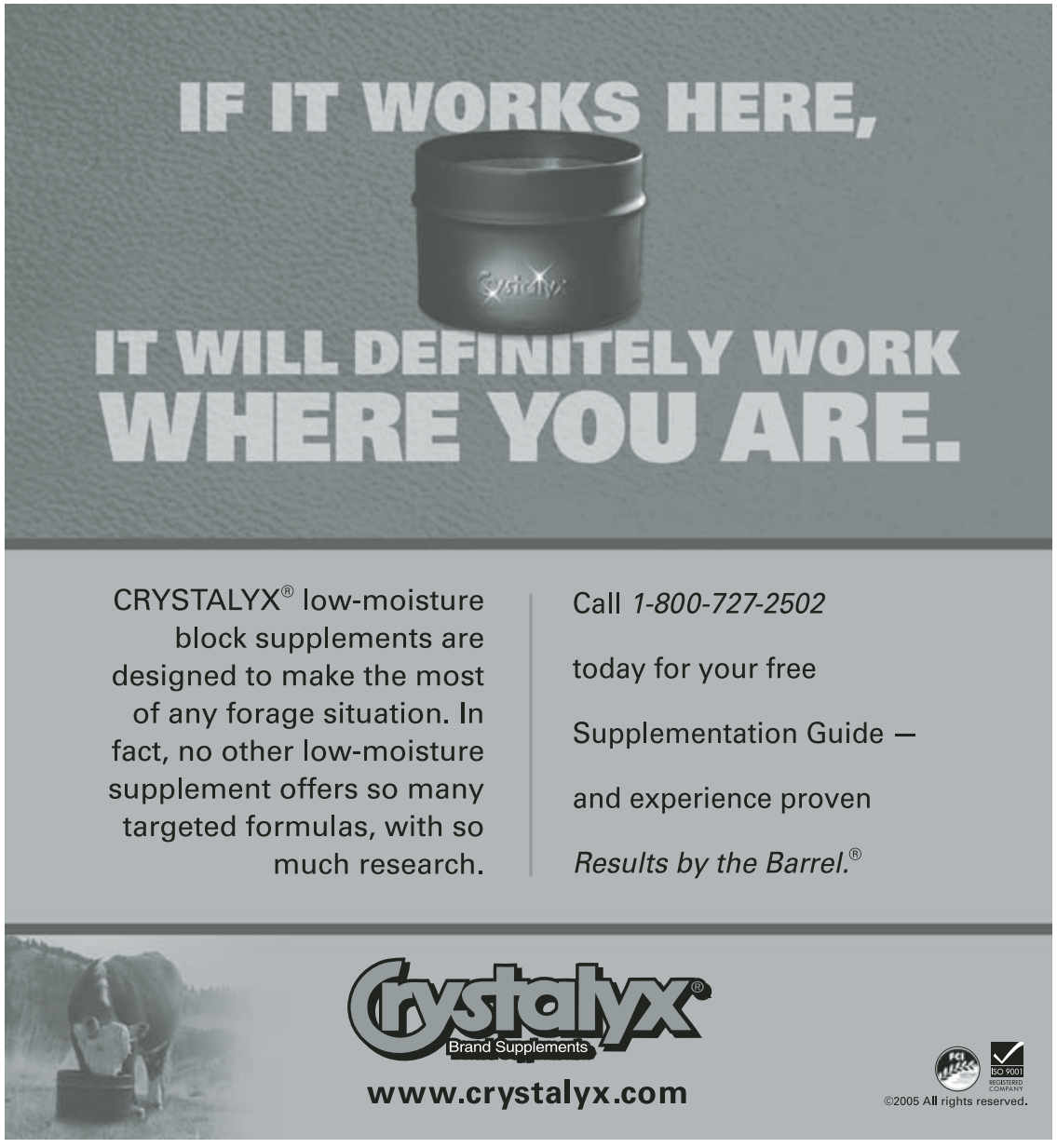

